\title{
Akdeniz İklim Koşullarında İkinci Ürün Olarak Yetiştirilen Krotalarya (Crotalaria juncea L.) Bitkisinde Farklı Gelişme Dönemlerinin Verim ve Bazı Yem Kalite Özelliklerine Etkileri
}

\author{
Gülcan Demiroğlu Topçu ${ }^{1^{*}}$ \\ Şükrü Sezgi Özkan ${ }^{1}$
}

${ }^{1}$ Ege Üniversitesi, Ziraat Fakültesi, Tarla Bitkileri Bölümü, İzmir

*Sorumlu yazar: gulcan.demiroglu.topcu@ege.edu.tr

Geliş Tarihi: 06.12.2018

Kabul Tarihi: 21.03.2019

\section{Öz}

$\mathrm{Bu}$ araştırma; Akdeniz iklim koşullarında yazlık ikinci ürün olarak yetiştirilen Krotalarya (Crotalaria juncea $\mathrm{L}$.) bitkisinde farklı gelişme dönemlerinin, verim ve bazı yem kalite özelliklerine etkilerini belirlemek amacıyla, Ege Üniversitesi Ziraat Fakültesi Tarla Bitkileri Bölümü’ne ait Bornova/İzmir'de yer alan deneme alanlarında 2 yıl süreyle (2016-2017) yürütülmüştür. Amerika Birleşik Devletleri’nden temin edilen Tillage Sun çeşidi bitkisel materyal olarak kullanılmıştır. Bitkiler farklı gelişme dönemlerinde (ekimden sonra 8-10-12-1416. hafta) hasat edilerek verim, verim unsurları ve bazı yem kalite özellikleri incelenmiştir. Denemeden elde edilen iki yıl ortalama sonuçlara göre; gelişme döneminin ilerlemesiyle; bitki boyu, sap çapı, yaprak sayısı, yeşil ot verimi, kuru madde verimi, NDF ve ADF değerlerinde artış kaydedilirken; yaprak oranı, ham protein ve ham kül oranlarında düşüş gözlemlenmiştir. Krotalarya bitkisinin yeşil ot verimleri $2917,0-11312,0 \mathrm{~kg} / \mathrm{da}$, kuru madde verimleri 693,0-3563,0 kg/da, ham protein oranları \%15,07-20,06, NDF değerleri \%60,82-66,61 ve ADF değerlerinin \%51,65-58,23 arasında değişim gösterdiği saptanmıştır. Sonuç olarak; ülkemizde Akdeniz iklim koşullarındaki yörelerde yazlık ikinci ürün olarak Krotalarya bitkisinin başarıyla yetiştirilebileceği kanaatine varılmıştır.

Anahtar Kelimeler: Krotalarya, Crotalaria juncea L., Gelişme dönemi, Verim, Yem kalitesi

\section{Effects of Different Growing Stages on The Yield and Some Forage Quality Characteristics of Sunn Hemp (Crotalaria juncea L.) Grown As Second Crop In Mediterranean Climate Condition \\ Abstract}

This research, in order to determine the effects of different growing stages on the yield and some forage quality characteristics in Sunn Hemp (Crotalaria juncea L.) grown as second crop in Mediterranean climate conditions, was carried out in the experimental areas of Ege University, Faculty of Agriculture, Department of Field Crops in Izmir/Turkey for 2 years (2016-2017). Tillage Sun cultivar obtained from The United States of America was used as plant material. Plants were harvested in different growing stages (after sowing 8-10-12-1416. weeks) and yield and some forage quality parameters were investigated. According to the two years average results; plant height, stem diameter, number of leaves, herbage yield, dry matter yield, NDF and ADF values were increased and such as rate of leaf, crude protein, crude ash rates were decreased. In Sunn hemp plants, NDF values varied from 60.82-66.61\%, ADF 51.65-58.23\%, herbage yield 2917.0-11312.0 kg/da, dry matter yields $693.0-3563.0 \mathrm{~kg} / \mathrm{da}$ and crude protein rates $15.07-20.06 \%$. As a result, it has been concluded that the Sunn hemp can be successfully grown as second crop in the regions under Mediterranean climate conditions in Turkey.

Keywords: Sunn Hemp, Crotalaria juncea L., Growing stage, Yield, Forage quality

Giriş

Crotalaria cinsi, Katırtırnağı Benzerleri Oymağ 1 (Genisteaea)'ndan olup, yaklaşık 600 adet türü kapsamaktadır. Cins adı olan Crotalaria, çıngırak anlamına gelmekte ve olgunlaşmış baklalarda tohumların çıkardığı gürültüyü ifade etmektedir (White and Haun, 1965). Bu cinsin türleri tropikal, sub-tropikal ve daha az 1lıman bölgelerde yayılış göstermekte ve 1lıman bölgelerde deniz seviyesinden 600 metre yüksekliğin altında kalan yörelerde yetiştirilebilmektedir (Ansari, 2008).

Crotalaria cinsinin en önemli türü olan ve Bengal Kendiri ya da Bombay Kendiri adı ile bilinen Crotalaria juncea L., genel olarak Hindistan'a özgü bir bitki olarak kabul edilmekte ve toprak 1slahı, lif üretimi ve yem bitkisi olarak kullanılmaktadır. Tropik bölgelerde, özellikle Endonezya, Malezya, Tayvan, Tayland ve Çin'de, yoğun olarak yeşil gübre bitkisi olarak yetiştirilmektedir. Güney Asya 
ülkelerinde ise eski yüzyıllardan beri önemli lif bitkilerinden biri olup, halat ve kâğıt yapımında kullanılmaktadır. Güney Afrika, Brezilya ve Hawaii gibi Dünya'nın diğer bölgelerinde çoğunlukla yeşil gübre ve örtü bitkisi olarak yetiştirilmektedir (Romin and Fitt, 1938; National Academy of Science, 1979; Rotar and Joy, 1983; Stallings, 2015; Demiroğlu Topçu et al., 2017; Demiroğlu Topçu ve Özkan, 2019).

Crotalaria juncea L., yaygın olarak tropik bölgelerde yetişen, 2.5-4 metre boylanabilen uzun boylu, dik gövdeli ve tek yıllık otsu bir baklagil bitkisidir. Uzunlamasına mızrak şeklinde olan yapraklar, basit yapıda ve sap boyunca spiral olarak dizilmiş olup, 0.5-3.0 cm genişliğinde, $4-12 \mathrm{~cm}$ uzunluğunda ve parlak yeşil renktedir. Bitki, güçlü kazık kök ve çok iyi gelişmiş yan köklere sahiptir. Sap çapı, 2 cm kalınlığında olabilmektedir. Kısa gün şartlarında yetiştirildiğinde çiçeklenmeye kadar ekimden itibaren yaklaşık 8 hafta sürmektedir. Çiçek, $8-20 \mathrm{~cm}$ uzunluğunda ve salkım şeklinde; çanak yaprak $1.5 \mathrm{~cm}$ uzunluğunda ve tüylü; taç yaprak ise $2-5 \mathrm{~cm}$ uzunluğunda ve parlak sarı renktedir. Meyve, silindirik bakla şeklinde, kısa kadifemsi tüylü, 6-12 tohum içermekte; tohumlar eğri kalp şeklinde 6-7 mm uzunlukta ve koyu kahverengi-siyah renkte olabilmektedir. Tohumlarının bin dane ağırlığı 35-50 gram civarındadır (Rotar and Joy, 1983; Chaudhury et al., 1997; Ansari, 2008; Mosjidis and Wang, 2011; Al-Snafi, 2016; Demiroğlu Topçu and Özkan, 2018).

Crotalaria juncea L., kendi cinsi içinde en agresif tür olarak bilinmektedir (Mosjidis and Wang, 2011). Ayrıca, 60 günde $2.700 \mathrm{~kg} / \mathrm{da}$ yeşil ot verimine ulaşabilmekte (Warren et al., 2012) ve hızlı gelişen bitkinin ekimden 60 gün sonra 1.2 metre ve 90 gün sonunda da 1.8 metreye ulaştığ 1 belirtilmektedir (Rotar and Joy, 1983; Mansoer et al., 1997). Bitkinin yapraklarının ise \%30 oranında protein içerdiği bilinmektedir (Warren et al., 2012; Mosjidis et al., 2013). Ayrıca Mansoer et al. (1997) yaptıkları çalışmada, her hasat zamanında yapraklardaki lignin, selüloz ve hemiselüloz oranlarının, saptaki oranlarından daha düşük olduğunu bildirmektedirler. Koyun ve keçilerin bitkinin yapraklarını ve üst kısımlarını tercih ettiği gözlemlenmiştir (Burke et al., 2011). Otlatma, bitkiler yaklaşık 45-90 cm uzunluğa geldiğinde başlatılabilmektedir. Yaprak kalitesi yüksek (yaklaşık \%4-5 N eşdeğeri \%2530 protein, \%22-28 NDF, \%22-27 ADF), sap kalitesi düşük (yaklaşık \%1.3-1.7 N eşdeğeri \%8-10 protein, \%74-76 NDF, \%64-65 ADF) olmasına rağmen; saplar ruminantların ihtiyaç duyduğu kaba yemi sağlayabilmektedir (Mosjidis et al., 2013). Bitki \%80 çiçeklendiğinde; yaklaşık \%35-40 biyokütlesi yapraklardan oluşmaktadır. Çiçeklenmeye kadar alt yaprakların bazılarının kaybolması yem kalitesinin düşmesine sebep olabilmektedir. Yem kullanımı amacıyla, erken gelişme dönemlerinde bitkiler daha az olgunlaşmakta ve yemde yaprak oranı artacağı için yem kalitesi de artmaktadır.

Hayvan beslemede kaba yemlerin kalitesini etkilediği düşünülen faktörlerin başında, çevre şartları, agronomik özellikler ve hasat zamanı gelmektedir (Buxton, 1996; Kamalak et al., 2005). Bitkilerin yaşlanması ile selüloz ve lignin miktarında görülen artışa bağlı olarak sindirim dereceleri düşmektedir (Morrison, 1980; Wilson et al., 1991; Van Soest, 1994). Bitkilerde gelişme döneminin ilerlemesiyle birlikte daha fazla selüloz ve lignin içeren sap oranında artış görülmekte ve buna bağlı olarak yaprak oranı azalmaktadır. Yem bitkilerinde gelişmenin ilerlemesine bağlı olarak sap oranı ve kuru madde veriminde artış, bununla birlikte bitkilerde yaprak oranı ve ham protein oranında ise azalmalar görülmektedir (Soya ve ark., 1999; Özyiğit ve Bilgen, 2003; Baytekin ve ark., 2003). Yaprak oranının fazla, su miktarı ve protein oranının da yüksek olduğu devrede gerçekleştirilen biçimler ile elde edilen yemlerin, hayvanlar tarafından sevilerek ve isteyerek tüketildiği bilinmektedir (Tekeli ve Ateş, 2007). Bunun yanı sıra, uygun olmayan devrelerde yapılan biçim işlemleriyle elde edilen kaba yemlerde ise hem ot kalitesinde düşüşler görülmekte, hem de bu yemleri tüketen hayvanlar yeterli ve dengeli şekilde beslenememektedirler.

$\mathrm{Bu}$ araştırmanın temel amacı, sıcaklıklarda artış görülen yaz mevsiminde yeşil yem ihtiyacının karşılanabilmesi amacıyla, ülkemizde ilk defa yetiştirilmek üzere, Amerika Birleşik Devletleri'nden getirilen tek yıllık, baklagil familyasına ait Crotalaria juncea L. bitkisinin Akdeniz ekolojisinde ikinci ürün koşullarına uyumu yanında, uygun gelişme döneminin belirlenmesi, aynı zamanda verim ve bazı yem kalite özelliklerinin saptanmasıdır.

\section{Materyal ve Metot}

Araştırma 2016-2017 yılları yaz mevsimi ikinci ürün koşullarında, iki yıl süreyle Ege Üniversitesi Ziraat Fakültesi Tarla Bitkileri Bölümü'ne ait deneme alanlarında yürütülmüştür. 
Çalışmanın yürütüldüğü yıllara ait iklim verileri Çizelge 1'de sunulmuştur (Anonim, 2018). Deneme yerinin 0-20 cm derinlikteki toprak özellikleri, milli-kil bünyeli, $\mathrm{pH}: 7.8$, organik madde $\% 1.13$, kireç $\% 21.52$, azot $\% 0.11$, fosfor $40 \mathrm{ppm}$ ve potasyum $400 \mathrm{ppm}$ değerlerini göstermektedir. Deneme yerinin iklim ve toprak özellikleri incelendiğinde, araştırmaya konu olan Crotalaria juncea L. bitkisinin yetiştiriciliği açısından kısıtlayıcı herhangi bir özellik göstermediği anlaşılmaktadır.

Çizelge 1. Araștırma yerine ait bazı iklim verileri

\begin{tabular}{lcccccc}
\hline & \multicolumn{3}{c}{ Ortalama Sicaklık $\left.\mathbf{(}^{\mathbf{0}} \mathbf{C}\right)$} & \multicolumn{3}{c}{ Toplam Yağış (mm) } \\
\cline { 2 - 7 } & $\mathbf{2 0 1 6}$ & $\mathbf{2 0 1 7}$ & UYO & $\mathbf{2 0 1 6}$ & $\mathbf{2 0 1 7}$ & UYO \\
\hline Temmuz & 29,3 & 29,0 & 28,0 & 0,0 & 0,0 & 2,0 \\
A ğustos & 28,9 & 28,6 & 27,6 & 0,4 & 0,1 & 2,2 \\
Eylül & 24,7 & 24,5 & 23,6 & 8,6 & 0,0 & 15,7 \\
Ekim & 19,5 & 18,5 & 18,8 & 0,5 & 61,3 & 44,3 \\
$X / \Sigma$ & 25,6 & 25,2 & 24,5 & 9,5 & 61,4 & 64,2 \\
\hline
\end{tabular}

UYO: Uzun Yillar Ortalamasi, X: ortalama, $\Sigma$ : toplam

Denemede Amerika Birleşik Devletleri'nden temin edilen Crotalaria juncea L. türüne ait Tillage Sun çeşidi bitkisel materyal olarak kullanılmıştır. Tesadüf blokları deneme desenine göre 3 tekerrürlü olarak düzenlenen denemede, ekim işlemleri $2 \mathrm{mx} 3 \mathrm{~m}$ 'lik parsellere dekara $5 \mathrm{~kg}$ tohum hesabıyla, her iki yılda Temmuz ayı başında yapılmıştır. Markör ile $20 \mathrm{~cm}$ sıra arası açılan çizilere el ile ekim işlemi gerçekleştirilmiştir. İki yılda da ekimlerden önce temel gübre olarak dekara $5 \mathrm{~kg} / \mathrm{da}$ saf $\mathrm{N}$ hesabıyla 15-15-15 kompoze gübresi uygulanmıştır. Araştırma süresince herhangi bir yabancı bitki savaşımı, hastalık ve zararlı mücadelesi yapılmamıştır (Şekil 1). Her gelişme döneminde (ekimden 810-12-14-16 hafta sonra), parseller el orağ 1 ile $1 \mathrm{~m}^{2}$ 'lik quadrat yardımıla toprak seviyesinden hasat edilmiştir. Çalışmada incelenen bitki boyu, sap çapı, yaprak sayısı, yaprak oranı, yeşil ot verimi, kuru madde verimi, ham protein oran1, ham kül oran1, NDF ve ADF özellikleri; Bulgurlu ve Ergül (1978), Van Soest (1994), Sarıçiçek (1995) ve Van Soest et al. (1991)'e göre saptanmıştır.

Araştırmada elde edilen bulgular; 2 yıllık ortalama değerlere göre düzenlenerek hazır paket program (TOTEMSTAT) yardımıyla varyans analizine tabi tutulmuş ve istatistikî olarak LSD \%5'e göre değerlendirilerek yorumlanmıştır (Açıkgöz ve ark., 1994).

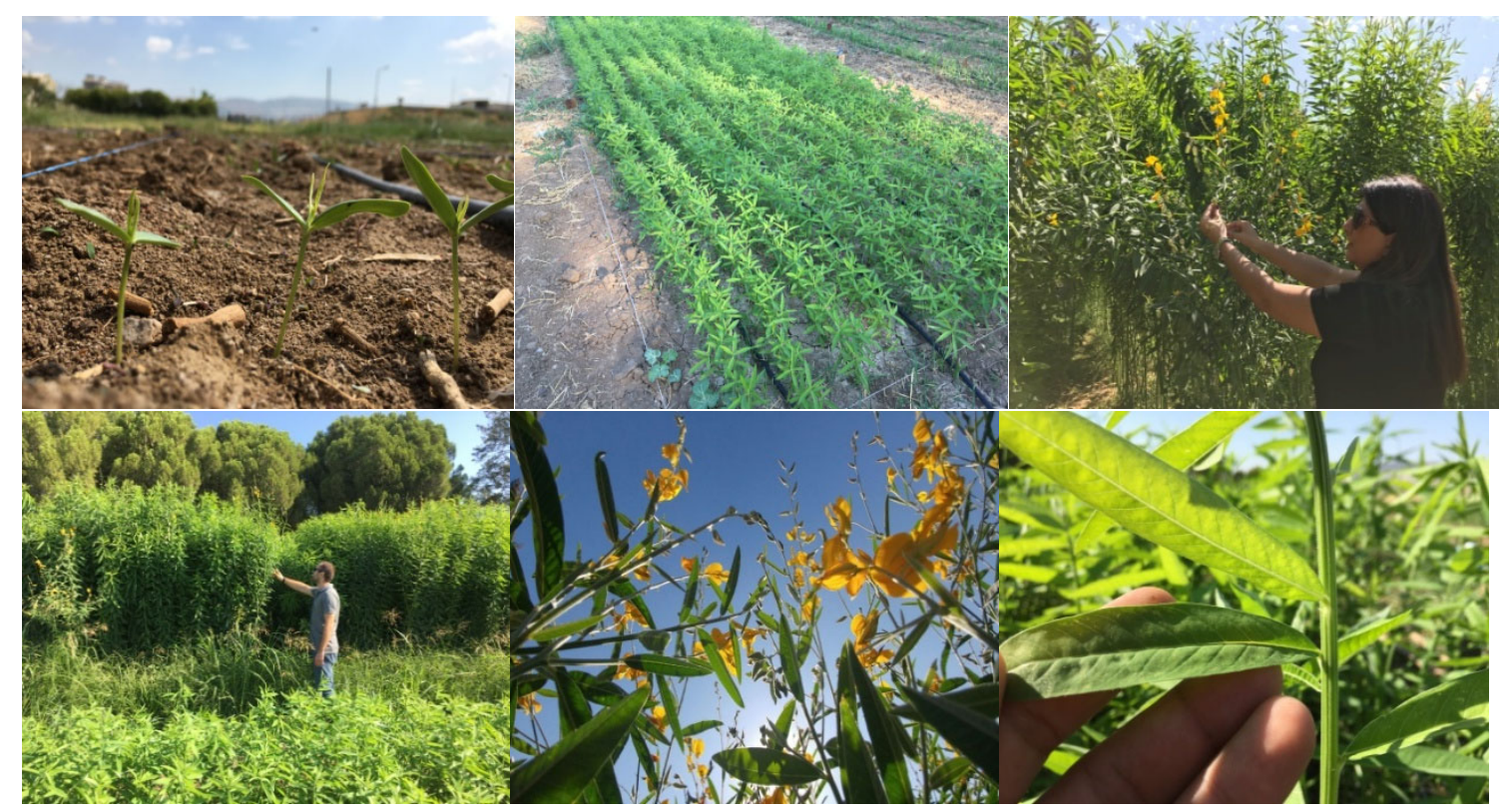

Şekil 1. Deneme alanındaki bitkilerin görünümleri

\section{Bulgular ve Tartışma}

Ülkemizde ilk defa yetiştiriciliği yapılan Krotalarya (Crotalaria juncea L.) bitkisinin, yazlık ikinci ürün koşulları altında farklı gelişme dönemlerindeki verim, verim unsurları ve bazı yem kalite 
özelliklerinin belirlenmesi amacıyla yürütülen bu çalışmada; bitki boyu, sap çapı, yaprak sayısı, yaprak oranı, yeşil ot verimi, kuru madde verimi, ham protein oranı, ham kül oranı, NDF ve ADF özelliklerine ait iki yıl ortalaması olarak düzenlenen değerler Çizelge 2’de verilmiştir.

Çizelge 2. Krotalarya bitkisinin farklı gelişme dönemlerinde verim ve bazı yem kalite özellikleri

\begin{tabular}{lccccc}
\hline $\begin{array}{l}\text { Ekimden } \\
\text { Sonra Geçen } \\
\text { Süre (Hafta) }\end{array}$ & $\begin{array}{c}\text { Bitki Boyu } \\
(\mathbf{c m})\end{array}$ & $\begin{array}{c}\text { Sap Çapi } \\
(\mathbf{m m})\end{array}$ & $\begin{array}{c}\text { Yaprak Sayısı } \\
\text { (adet/bitki) }\end{array}$ & $\begin{array}{c}\text { Yaprak Oranı } \\
\mathbf{( \% )}\end{array}$ & $\begin{array}{c}\text { Yeşil Ot } \\
\text { Verimi } \\
(\mathbf{k g} / \mathbf{d a})\end{array}$ \\
\hline 8 & $170,2 \mathrm{c}$ & $6,50 \mathrm{c}$ & $64,3 \mathrm{e}$ & $35,82 \mathrm{a}$ & $2917,0 \mathrm{e}$ \\
10 & $208,2 \mathrm{~b}$ & $7,53 \mathrm{bc}$ & $75,4 \mathrm{~d}$ & $31,28 \mathrm{~b}$ & $4630,0 \mathrm{~d}$ \\
12 & $229,0 \mathrm{a}$ & $7,89 \mathrm{~b}$ & $92,4 \mathrm{c}$ & $28,95 \mathrm{~b}$ & $7460,0 \mathrm{c}$ \\
14 & $233,2 \mathrm{a}$ & $9,11 \mathrm{a}$ & $109,2 \mathrm{~b}$ & $27,91 \mathrm{bc}$ & $9198,0 \mathrm{~b}$ \\
16 & $234,4 \mathrm{a}$ & $9,36 \mathrm{a}$ & $125,2 \mathrm{a}$ & $25,06 \mathrm{c}$ & $11312,0 \mathrm{a}$ \\
\hline Ortalama & 215,0 & 8,08 & 93,3 & 29,80 & 7103,0 \\
\hline LSD (0.05) & 5,81 & 1,20 & 4,55 & 3,55 & 349 \\
\hline Ekimden & Kuru Madde & Ham Protein & Ham Kül & $\mathbf{N D F}$ & ADF \\
Sonra Geçen & Verimi & Oranı & Oranı & $\mathbf{( \% )}$ & $\mathbf{( \% )}$ \\
Süre (Hafta) & $\mathbf{( k g / \text { da) }}$ & $\mathbf{( \% )}$ & $\mathbf{( \% )}$ & & $51,65 \mathrm{~d}$ \\
\hline 8 & $693,0 \mathrm{e}$ & $20,06 \mathrm{a}$ & $7,58 \mathrm{a}$ & $60,82 \mathrm{~d}$ & $53,56 \mathrm{c}$ \\
10 & $1101,0 \mathrm{~d}$ & $18,65 \mathrm{~b}$ & $6,97 \mathrm{~b}$ & $62,26 \mathrm{c}$ & $56,28 \mathrm{~b}$ \\
12 & $2125,0 \mathrm{c}$ & $16,79 \mathrm{c}$ & $6,37 \mathrm{bc}$ & $64,23 \mathrm{~b}$ & $56,62 \mathrm{~b}$ \\
14 & $2755,0 \mathrm{~b}$ & $15,58 \mathrm{~d}$ & $6,29 \mathrm{bc}$ & $65,05 \mathrm{~b}$ & $58,23 \mathrm{a}$ \\
\hline 16 & $3563,0 \mathrm{a}$ & $15,07 \mathrm{~d}$ & $6,45 \mathrm{c}$ & $66,61 \mathrm{a}$ & 55,27 \\
\hline Ortalama & 2,047 & 17,23 & 6,73 & 63,79 & 1,34 \\
\hline LSD $(0.05)$ & 155 & 0,79 & 0,61 & 1,30 & \\
\hline
\end{tabular}

Bitki Boyu (cm) ve Sap Çapı $(\mathbf{m m})$ : Krotalarya bitkisinde bitki boyuna ilişkin veriler incelendiğinde, gelişme dönemleri bakımından istatistikî olarak \%5 ihtimal sınırına göre önemli farklılıklar bulunmuştur. Yapılan araştırmada gelişme dönemleri bitki boylarını önemli derecede etkilemiş ve Akdeniz ekolojik koşulları altında yazlık ikinci ürün yetiştirme sezonu boyunca bitki boyunda artış gözlenmiştir (Çizelge 2). Ancak 12. haftadan sonra 16. haftaya kadar olan dönemde bitki boyundaki artış miktarının azaldığı saptanmıştır. Bitki boyuna ilişkin bulgular; Rotar and Joy (1983), Mansoer et al. (1997), Ansari (2008), Mosjidis and Wang (2011), Warren et al. (2012), Cho et al. (2013) ve Tripathi et al. (2013) tarafindan değişik genotip ve ekolojilerde yetiștirilen Krotalarya bitkisinin bitki boyu değerleri ile paralellik göstermektedir.

Krotalarya bitkisinde, sap çapı bakımından gelişme dönemleri arasında istatistikî olarak \%5 düzeyinde önemli farklılıklar bulunmuştur. En düşük sap çap1 6,50 mm ile ekimden sonra 8. haftada, en yüksek sap çap1 ise $9,36 \mathrm{~mm}$ ile ekimden sonra 16 . haftada gerçekleştirilen hasatlardan kaydedilmiştir. Elde edilen veriler, sap çapındaki artış miktarının 14. haftadan sonra azaldığını göstermektedir. Sap çapına ait bulgular, bazı araştırıcıların sonuçlarıyla uyumlu bulunmuştur (Ansari, 2008; Tripathi et al., 2013).

Yaprak Sayısı (adet/bitki) ve Yaprak Oranı (\%): Krotalarya bitkisinde gelişme dönemlerine göre yaprak sayısı arasında önemli farklılıkların olduğu saptanmıştır. Bitkide yaprak sayısı, gelişim dönemlerine göre 64,3-125,2 arasında değişmiştir. Ekimden 8 hafta sonra gerçekleştirilen hasatta 64,3 ile en düşük yaprak sayısı elde edilmiş ve ekimden 16 hafta sonra gerçekleştirilen hasatta ise 125,2 ile en yüksek yaprak sayısına ulaşılmıştır. Cho et al. (2013), bitki gelişmesinin ilerlemesiyle yaprak sayısında düzenli olarak artış görüldüğünü öne sürmektedirler. Akdeniz ekolojik koşulları altında yazlık ikinci ürün yetiştirme sezonu boyunca da yaprak sayılarında artış gözlenmiştir.

Çizelge 2 incelendiğinde, gelişme dönemlerinin gecikmesi ile beklenildiği gibi bitki boyu ve sap çapındaki artışa bağlı olarak, bitkilerin yaprak oranlarında azalma gözlemlenmiş ve ekimden 16 hafta sonra gerçekleştirilen biçimde $\% 25,06$ ile en düşük yaprak oranı elde edilmiştir. İlerleyen gelişme dönemlerinde yaprak sayısında artış görülmesine rağmen, bitkinin sap gelişiminin yaprak gelişiminden fazla olmasından dolayı, yaprak oranının da azaldığı düşünülmektedir. Bitkide yaprak/sap oranı, yem kalitesinin önemli bir göstergesidir. Sapların yapraklara kıyasla kalitesi daha düşüktür ve bitki 
yaşlandıkça sap oranında artış gözlenmektedir (Açıkgöz, 2001). Bulgularımız, Krotalarya bitkisinde gelişme döneminin ilerlemesiyle yaprak sayısının arttığını, buna karşın sap çapının da arttığını ve bu nedenle de ağırlık esasına göre belirlenen yaprak oranı değerlerinin de azaldığını göstermektedir.

Yeşil Ot Verimi (kg/da) ve Kuru Madde Verimi (kg/da): Bitkilerin yetiştirildikleri ekolojilerde gösterdikleri adaptasyon yeteneklerini karşılaştırmak için incelenen ilk özelliklerden biri olan yeşil ot verimi; bitki cinsi ve türü, birim alanda yetiştirilen bitki sayısı, bitkinin olgunlaşma süresi, bitkiden yararlanma şekli, biçim zamanı, uygulanan tarım teknikleri gibi unsurlardan doğrudan etkilenen kantitatif bir karakterdir (Gençtan, 1998; Soya ve ark., 2001). Yeşil ot verimi açısından iki y1l ortalamaları incelendiğinde en yüksek verimin $11312,0 \mathrm{~kg} / \mathrm{da}$ ile ekimden 16 hafta sonra elde edildiği görülmektedir (Çizelge 2). Ekimden 8 hafta sonra ise 2917,0 kg/da ile en düşük verim elde edilmesine karşın, bu değerin diğer baklagil yem bitkileri ile karşılaştırıldığında oldukça tatmin edici olduğu düşünülmektedir. Yeşil ot verime ilişkin elde edilen bulgular; Warren et al. (2012), Cho et al. (2013) ve Srisaikham and Lounglawan (2017) gibi bazı araştırıcıların, son yıllarda değişik genotip ve ekolojilerde gerçekleştirdikleri çalışmalarının sonuçlarıyla benzerlik göstermektedir.

Gelişme dönemlerinin gecikmesi ile beklenene uygun şekilde bitkilerin kuru madde üretim miktarlarının artmasına bağlı olarak kuru madde verimlerinin de hızlı bir artış gösterdiği ve ekimden 16 hafta sonra gerçekleştirilen biçimde $3563,0 \mathrm{~kg} / \mathrm{da}$ ile en yüksek kuru madde verimine ulaşı1dığ görülmektedir (Çizelge 2). Gerek Krotalarya gerekse diğer baklagil yem bitkileri ile yapılan araştırmalarda, ilerleyen gelişme dönemleri ile birlikte verimlerde artış gözlendiği pek çok araştırıcı tarafindan bildirilmektedir (Salisbury ve Ross, 1992; Mansoer et al., 1997; Fraser et al., 2001; Borreani et al., 2007; Türk et al., 2007; Cho et al., 2013; Srisaikham and Lounglawan, 2017).

Ham Protein Oranı (\%) ve Ham Kül Oranı (\%): Ham protein oranı özelliği, bitkilerin yapısına katılan, birçok durumda aminoasitlerin kondensasyonu sonucu yedek besin olarak depo edilen ve yem bitkilerinde önemli kalite kriterlerinin başında gelmektedir. Denemede organik madde içinde, kimyasal analiz sonucunda belirlenen azotun, 6,25 ile çarpılması sonucuyla belirlenen ham protein oranlarının (Kaya, 1997), araştırmada incelenen gelişme dönemlerinin farklılıklarından dolayı değişkenlik gösterdiği düşünülmektedir. Ham protein oranına bitki kısımlarının (yaprak, sap, vb) içerdiği azot miktarları etki yapmaktadır. Bu kısımlar vejetasyon dönemi süresince kuvvetli fotoperiyodik ve termoperiyodik etkilere maruz kalmaktadırlar ve bu nedenle dokularındaki azot rezervleri ciddi farkl1l1klar göstermektedir. Bitkilerde gelişme dönemi ilerledikçe ham protein oranı değerlerinin de azaldığı bilinmektedir. Nitekim ekimden sonra geçen sürenin artması ile ham protein oranlarının azaldığı bulgularımızda gözlenmiştir. Ekimden 8 hafta sonra elde edilen ham protein oranı $\% 20,06$ olurken, ekimden 16 hafta sonra elde edilen değer \%15,07 olarak tespit edilmiştir (Çizelge 2). Krotalarya bitkisi ile çalışan pek çok araştırıcı da elde edilen verilere benzer şekilde gelişmenin ilerlemesiyle ham protein oranının azaldığını belirtmektedirler (Mansoer et al., 1997; Cho et al., 2013; Mosjidis et al., 2013; Forsythe et al., 2017; Srisaikham and Lounglawan, 2017). Bitkilerin erken gelişme dönemlerinde sap kısımları, yapraklar kadar besleyici olmalarına rağmen, daha sonraki dönemlerde sapların besin değerleri hızla azalmaktadır. Bu nedenle de ham protein oranı değerlerinde azalma gözlenmektedir. Araştırmada elde edilen bulguların diğer araştırıcıların sonuçları ile uyumlu olduğu kanaatine varılmıştır.

Bitki hücrelerinin fonksiyonlarının etkinliği için hayati öneme sahip olan nükleoproteinlerin yapısında bulunan ve oksijenin taşınması vb. gibi çok sayıda olayda rol alan mineralleri içeren ham kül değerleri, bitkide kuru maddenin yakılmasından sonra arta kalan ve yanmayan fraksiyon olarak tanımlanmaktadır (Gençtan, 1998). Ekimden sonra geçen sürenin ilerlemesi ile ham kül oranlarının azaldığı izlenmektedir. Ekimden 8 hafta sonra elde edilen ham kül oranı değeri \%7,58 olurken, ekimden 16 hafta sonra bu değerin \%6,45'e düştüğü gözlenmiştir (Çizelge 2). Bulgularımız, Krotalarya' da gelişme döneminin ilerlemesiyle ham kül oranı değerlerinin azaldığını bildiren Srisaikham and Lounglawan (2017) ile paralellik göstermektedir.

NDF (\%) ve ADF (\%): Nötr deterjanda çözünmeyen lif (NDF), hücre duvarı ve hücre içeriğini kimyasal olarak ayrıştıran bir metot olarak tanımlanmaktadır. Bu ayrıştırma işlemi sonucunda hücre duvarına bağlı bulunan protein, nitrojen ve mineral gibi moleküller hücre duvarı yapısı ile birlikte kalmaktadır (Van Soest, 1994). Krotalarya bitkisinin NDF özelliğine ait bulgular incelendiğinde, gelişme dönemleri arasında önemli farklılıklar tespit edilmiştir. Denemede bitkisel materyalin NDF oranının \%60,82-66,61 arasında değişim gösterdiği saptanmıştır. Ekimden 8 hafta sonra $\% 60,82$ ile en 
düşük değer, ekimden 16 hafta sonra ise \%66,61 ile en yüksek NDF oranı elde edilmiştir. Bitkide yaprak/sap oranı yem kalitesini yakından etkilemektedir. Sapların yapraklara kıyasla kalitesi daha düşüktür. Bitki yaşlandıkça sap oranında artış görülmekte ve NDF oranları yükselmeye başlamaktadır. $\mathrm{Bu}$ durum sindirilme oranlarında azalmaya sebep olmaktadır. Ayrıca, bitkide gelişme döneminin ilerlemesiyle beraber hücre duvarlarının temel yapı taşı olan ham selüloz üretimi sap ve yapraklarda artış göstermekte, bu durumda yine NDF oranı yükselmektedir. Bitkide NDF miktarı arttıkça, NDF içinde yer alan çözünebilen maddeler düşmektedir. Tüm bu bilgilerden, bir kaba yemin toplam NDF içeriğinin, kaba yemin genel kalitesini ve sindirilebilirlik değerini ortaya koyan önemli bir ölçüt olduğu anlaşılmaktadır (Oba and Allen, 1999). Araştırmada elde ettiğimiz NDF oranı ile ilgili bulgularımız, bazı araştııııların, Krotalarya bitkisinin farklı genotiplerle ve değişik ekolojilerde inceledikleri çalışmalarının sonuçlarıyla benzerlik göstermektedir (Mansoer et al., 1997; Mosjidis et al., 2013; Forsythe et al., 2017; Srisaikham and Lounglawan, 2017).

Asit deterjanda çözünmeyen lif (ADF) ise, bitkide NDF değerinden hemiselüloz miktarının çıkarılması sonucu kalan kısım olarak tanımlanmaktadır. Bu özellik, bitkinin sindirilebilirliği ve hayvanın bitkiden enerji alımı hakkında fikir veren bir göstergedir (Van Soest, 1994). Araştırmada elde edilen ADF değerlerinde, gelişme dönemlerine göre önemli farkl1lıklar izlenmektedir (Çizelge 2). Krotalarya bitkisinin ADF içeriği \%51,65-58,23 arasında değişim göstermiş; ekimden 8 hafta sonra $\% 51,65$ ile en düşük değer, ekimden 16 hafta sonra ise \%58,23 ile en yüksek ADF oranı elde edilmiştir. Krotalarya bitkisinde gelişim dönemleri ilerledikçe, beklenildiği gibi ADF oranlarında bir yükseliş meydana geldiği belirlenmiştir. Mansoer et al. (1997), Mosjidis et al. (2013), Forsythe et al. (2017) ve Srisaikham and Lounglawan (2017), Krotalarya bitkisinde gelişme dönemi ilerledikçe ADF değerlerinin de buna bağlı olarak arttığını ve sindirilme derecesinin düştüğünü bildirmişlerdir. Elde ettiğimiz sonuçlar diğer araştırıcıların bulgularıyla uyum göstermektedir.

\section{Sonuç ve Öneriler}

Akdeniz ikliminin hâkim olduğu Bornova/İzmir koşullarında 2 yıl süreyle yürütülen bu çalışmada, Krotalarya bitkisinde, farklı gelişme dönemlerinin verim ve bazı yem kalite özellikleri üzerine önemli etkilerinin olduğu saptanmıştır. Elde edilen bulgular, gelişme döneminin ilerlemesiyle bitki boyu, sap çapı, yaprak sayısı, yeşil ot verimi, kuru madde veriminde artış olduğunu; yaprak oranı, ham protein oranı ve ham kül oranı özelliklerinde ise düşüş gözlemlendiğini ortaya koymuştur. Diğer taraftan, bitkinin yaşlanması sonucu selüloz ve lignin miktarının artmasına bağlı olarak, NDF ve ADF oranları artmış, bu nedenle yemin sindirilme derecesinde azalma meydana gelmiştir.

Araştırma sonuçları, son yıllarda önemi giderek artan ve ülkemizde yürütülen hayvancılık faaliyetlerinin en önemli sorunlarından biri olan kaliteli kaba yem temininin sağlanması amacıyla, Akdeniz ekolojik koşulları altındaki yörelerimizde Krotalarya (Crotalaria juncea L.) bitkisinin ümitvar sonuçlar verdiğini göstermektedir. Özellikle yazlık tek yıllık baklagil yem bitkisi alternatiflerinin kısıtlı olduğu ülkemizde, çok yönlü özellikleri bulunması dolayısıyla çeşitli amaçlarla kullanılma potansiyeli de yüksek görülen Krotalarya bitkisinin, Tarım ve Orman Bakanlığı'nın farklı birimleriyle ülkemiz üreticisine tanıtılması, üniversite ve araştırma enstitülerinde bitkiyle ilgili daha verimli ve besin değeri yüksek çeşitlerin geliştirilmesi yanında ekim normu, gübreleme, sulama vb. diğer konulardaki çalışmaların ülkemizin benzer ekolojilerinde de yürütülmesi gerektiği düşünülmektedir.

Kaynaklar

Açıkgöz, E., 2001. Yem Bitkileri. Uludağ Üniversitesi. Güçlendirme Vakfı Yayın No: 182. Vipaş A.Ş. Yayın No:58, 584s., Bursa.

Açıkgöz, N., Akbaş, M.E., Moghaddam, A., Özcan, K., 1994. Pc’ler için veri tabanı esaslı Türkçe istatistik paketi: TARISTT. Tarla Bitkileri Kongresi, 25-29 Nisan 1994, Bornova-İzmir, 131-136s.

Al-Snafi, A.E., 2016. The contents and pharmacology of Crotalaria juncea-A review. 6(6):77-86.

Anonim, 2018. İzmir İli'nin İklim Durumu ve Verileri, T.C. Tarım ve Orman Bakanlığı, Meteoroloji Genel Müdürlüğü, Meteoroloji 2. Bölge Müdürlüğü, İzmir.

Ansari, A.A., 2008. Crotalaria L. India. Bishen Singh Mahendra Pal Singh, Dehra Dun, 378p.

Baytekin H., Hakyemez, B.H., Özer, İ., Gökkuş, A., 2003. Çanakkale'de taban ve kıraç koşullarda kışlık ara ürün olarak yetiştirilen fiğde hasat zamanının ot verimi ve bazı tarımsal özelliklere etkisi. Türkiye 5. Tarla Bitkileri Kongresi. s.70-73, 13-17 Ekim 2003, Diyarbakır. 
Borreani G., Giorgio Peiretti, P., Tabacco, E., 2007. Effect of harvest time on yield and pre-harvest quality of semi-leafless grain peas (Pisum sativum L.) as whole-crop forage. Field Crops Research. 100: 1-9.

Bulgurlu, Ş., Ergül, M., 1978. Yemlerin Fiziksel, Kimyasal ve Biyolojik Analiz Metodları, Ege Üniversitesi Ziraat Fakültesi Yayınları No:127, Ege Üniversitesi Matbaası, Bornova-İzmir, 58-76s.

Burke, J.M., Mosjidis, J.A., Miller, J.E., Casey, P., 2011. Sunn hemp with chicory or pearl millet to minimize gastrointestinal nematode infection in weaned goats. J. Anim. Sci. 89 (E-Suppl.2):17-18 (Abstr.).

Buxton, D.R., 1996. Quality-related characteristics of forages as influenced by plant environment and agronomic factors. Animal feed science and technology. 59(1):37-49.

Chaudhury, J., Singh, D.P., Hazra, S.K., 1997. Sunnhemp (Crotalaria juncea L.). Central Research Institute for Jute and Allied Fibres (ICAR), Tech. Bull. No. 5, pp 1-50.

Cho, H.S., Seong, K.Y., Park, T.S., Seo, M.C., Kim, M.H., Kang, H.W., Lee, H.J., 2013. Effect of seeding rate of Crotalaria (Crotalaria juncea L.) on Green Manure Yield and Nitrogen Prodution in Upland Soil. Korean Journal of Soil Science and Fertilizer. 46(6):445-451.

Demiroğlu Topçu, G., Özkan, Ş.S., 2018. A Preliminary Study on The Adaptation of Sunn Hemp (Crotalaria juncea L.) In Mediterranean Climatic Conditions, 2nd International Vocational Science Symposium, 2629 April 2018, Abstract Book, Pp:199, Antalya/Turkey.

Demiroğlu Topçu, G., Özkan, Ş.S., Özçelik, A.E., Acaroğlu, M., 2017. Investigation of Agronomic Techniques of Sunn Hemp (Crotalaria juncea L.) as an Alternative Forage and Energy Crop in Turkey, 1st International Conference on Energy and Thermal Engineering, 25-28 April 2017, Proceedings Book, Pp:333, Istanbul/Turkey.

Demiroğlu Topçu, G., Özkan, Ş.S., 2019. Akdeniz Ekolojik Koşulları için Alternatif Bir Bitki: Crotalaria juncea L. (Krotalarya), KSÜ Tarım ve Doğa Dergisi. 22(2):340-346.

Forsythe, E.T., Lepcha, I., Naumann, H.D., 2017. Partitioning of nutritive value in Crotalaria juncea L. (Sunn Hemp). Managing Global Resources for a Secure Future, 2017 Annual Meeting, Oct. 22-25, Tampa, FL.

Fraser M.D., Fychan, R., Jones, R., 2001. The effect of harvest date and inoculation on the yield, fermentation characteristics and feeding value of forage pea and field bean silages. Grass and Forage Science. 56: 218230.

Gençtan, T., 1998. Tarımsal Ekoloji. Trakya Üniversitesi Tekirdağ Ziraat Fakültesi, Tarla Bitkileri Bölümü, Tekirdağ, 191s.

Kamalak A., Canbolat, O., Gurbuz, Y., Erol, A., Ozay, O., 2005. Effect of maturity stage on chemical composition, in vitro and in situ dry matter degradation of tumbleweed hay (Gundelia tournefortii L.). Small Ruminant Research. 58:149-156.

Kaya, N., 1997. Biyokimya. Ege Üniversitesi Ziraat Fakültesi Yayınları Ders Notları No:54/1, E.Ü. Ofset Basımevi, Bornova-İzmir, 138s.

Mansoer, Z., Reeves, D.W., Wood, C., 1997. Suitability of sunn hemp as an alternative late-summer legume cover crop. Soil Science Society of America Journal. 61(1):246-253.

Morrison, I.M., 1980. Changes in the lignin and hemicellulose concentrations of ten varieties of temperate grasses with increasing maturity. Grass Forage Sci. 35: 287-293.

Mosjidis, J.A., Balkcom, K.S., Burke, J.M., Casey, P., Hess, J.B., Wehtje, G., 2013. Production of the Sunn Hemp Cultivars: 'AU Golden' and 'AU Durbin' developed by Auburn University. Technical Rep, No:328, 7p.

Mosjidis, J.A., Wang, M.L., 2011. Crotalaria. In: C. Kole, editor, Wild crop relatives: Genomic and breeding resources, Industrial Crops. Springer-Verlag Berlin Heidelberg. p.63-69.

National Academy of Science, 1979. Sunnhemp. In: Advisory committee on technology innovation, tropical legumes: Resources for the future. National Academy of Science, Washington, DC., p. 272-278.

Oba, M., Allen, M.S., 1999. Evaluation of the important of the digestibility of neutral detergent fiber fromforage: Effects on dry matter intake and milk yield of dairy cows. J. Dairy Sci. 82:589-596.

Özyiğit Y., Bilgen, M., 2003. Arı Bitkisi Olarak Değerlendirilebilecek Bazı Baklagil Yem Bitkilerinde Farklı Biçim Dönemlerinin Verim ve Tarımsal Özellikler Üzerine Etkisi. Türkiye 5. Tarla Bitkileri Kongresi. 479-483. 13-17 Ekim 2003, Diyarbakır.

Romin, A.E., Fitt, R.H., 1938. The feeding of sunnhemp hay (Crotalaria juncea) as compared with cowpea hay (Vigna catjang) in a fattening ration for bullocks. Rhod. Agric. J. 35:15-19.

Rotar, P.P., Joy, R.J., 1983. 'Tropic Sun' sunn hemp, Crotalaria juncea L. Research Extension Series 036, University of Hawaii, Honolulu.

Salisbury, F.B., Ross, C.W., 1992. Plant Physiology. Wadsworth Pub. Com., Inc., Belmont, California-USA.

Sarıçiçek, B.Z., 1995. Yemler Bilgisi Laboratuvar Kılavuzu. Ondokuz Mayıs Üniversitesi Ziraat Fakültesi Ders Notu No:16, Samsun, 68s.

Soya, H., Avcıŏlu, R., Geren, H., Cevheri, A.C., 2001. Bazı Silajlık Mısır (Zea mays L.) Çeşitlerinde Hasıl Verimi ve Diğer Bazı Verim Özellikleri Üzerine Araştırmalar, E.Ü. Araştırma Fon Saymanlığı 1999ZRF-007 No'lu Proje, Bornova/İzmir, 65s. 
Soya, H., Doğrucu, F., Geren, H., Kır, B., 1999. Adi Fiğ (Vicia sativa L.) ve tüylü fiğ (Vicia villosa)'de farklı biçim zamanlarının ot verimi ve verim özelliklerine etkisi üzerine bir araştırma. Türkiye 3. Tarla Bitkileri Kongresi. Cilt: III: 92-95. 15-18 Kasim 1999, Adana.

Srisaikham, S., Lounglawan, P., 2017. Effect of cutting age and cutting height on production and nutritive value of sunnhemp (Crotalaria juncea) harvest in Nakhon Ratchasima, Thailand. IV Asia Symposium on Quality Management in Postharvest Systems 1210, pp. 29-34.

Stallings, A., 2015. Sunn hemp (Crotalaria juncea L.) as a Cover Crop for Winter Wheat. Graduate Faculty of Auburn University, Master thesis, $144 \mathrm{p}$.

Tekeli, A.S., Ateş, E., 2007. Farklı biçim dönemlerinin yem bezelyesi (Pisum arvense L.)-buğday (Triticum aestivum L.) karışımının yem verimi ve kalitesi ile tetani oranına etkileri. Türkiye VII. Tarla Bitkileri Kongresi. 106-109. 25-27 Haziran 2007, Erzurum.

Tripathi, M.K., Chaudhary, B., Singh, S.R., Bh, H.R., 2013. Growth and yield of sunnhemp (Crotalaria juncea L.) as influenced by spacing and topping practices. African Journal of Agricultural Research. 8(28):37443749.

Türk, M., Albayrak, S., Yüksel, O., 2007. Effects of phosphorus fertilisation and harvesting stages on forage yield and quality of narbon vetch. New Zealand Journal of Agricultural Research. 50: 457-462.

Van Soest, P.J., 1994. Fiber and physicochemical properties of feeds in: Nutritional ecology of the ruminant. Second edition. Cornell University press. Ithaca, NY.

Van Soest, P.J., Robertson, J.B., Lewis, B.A., 1991. Methods for dietery fiber, neutral detergent fiber, and non starch polysaccharides in relation to animal nutrition. J. Dairy Sci. 74:3583-3597.

Warren, J., Wilson, T., Edwards, J., 2012. Using sunnhemp as a cover crop in Oklahoma. Oklahoma Cooperative Extension Service, PSS-2273.

White, G.A., Haun, J.R., 1965. Growing Crotalaria juncea, a multi-purpose fiber legume, for paper pulp. Econ. Bot. 19:175-183.

Wilson, J.R., Deinum, B., Engels, F.M., 1991. Temperature effects on anatomy and digestibility of leaf and stem of tropical and temperate forage species. Neth. J. Agric. Sci. 39:31-48. 